\title{
SESAME News
}

No. 7

June 1981

A series of informative contributions concerning the SESAME project and its 1979 field program, supported by the National Oceanic and Atmospheric Administration, the National Aeronautics and Space Administration, the National Science Foundation, and others. Prospective contributions should be sent to Professor Frederick Sanders, Department of Meteorology, Massachusetts Institute of Technology, Cambridge, Mass. 02139

\section{Attenuation Problems Associated with a $5 \mathrm{~cm}$ Radar}

\author{
Robert H. Allen ${ }^{1}$, Donald W. Burgess ${ }^{2}$, and Ralph J. Donaldson, Jr. ${ }^{3}$
}

\begin{abstract}
The reflectivity pattern from a $5 \mathrm{~cm}$ Doppler radar is compared to that from a colocated $10 \mathrm{~cm}$ Doppler radar to determine the relative attenuation of the $5 \mathrm{~cm}$ signal. Maximum attenuation occurred on 10 April 1979 during the alignment of two severe thunderstorms on the same radar azimuth. During alignment, the near-range storm caused total attenuation of the $5 \mathrm{~cm}$ signal from the far-range storm. Maximum attenuation in the far-range storm was much in excess of $23 \mathrm{~dB}$. was on the order of $30 \mathrm{~dB}$. Characteristics of the two storms are presented, along with the rainfall rate (maximum of $6.4 \mathrm{in} \mathrm{h}^{-1}$, of the Maximum attenuation in the back side of the near-range storm was on the order of $30 \mathrm{~dB}$. Characteristics of the two storms are presented, along with the rainfall rate (maximum of $6.4 \mathrm{in} \mathrm{h}^{-1}$ ) of the near-range storm, a reflectivity contour analysis for each radar, and difference fields showing the attenuation of the $5 \mathrm{~cm}$ signal in both storms. Some operational problems associated with a $5 \mathrm{~cm}$ radar in an attenuating environment include degradation of peak values and distortion of severe weather indicators, as well as the possibility of the loss of the capability to detect severe storms.
\end{abstract}

\section{Introduction}

Numerous studies have focused on the attenuation problems associated with radars operating at wavelengths of less than $10 \mathrm{~cm}$. For example, Wilson (1978) examined the heavy attenuation of $5 \mathrm{~cm}$ radar signals in Colorado hailstorms. More recently, Metcalf (1980) discussed the key role of attenuation in the 1977 crash of Southern Airways Flight 242. The radar echo patterns were seriously distorted by severe attenuation in this major fatal accident. Finally, this article is a follow-up on preliminary results presented by Allen et al. (1980).

\footnotetext{
${ }^{1}$ Air Weather Service, Scott AFB, Ill. 62225.

${ }^{2}$ National Severe Storms Laboratory, Norman, Okla. 73069.

${ }^{3}$ Air Force Geophysics Laboratory, Hanscom AFB, Mass. 01731.
}

During the spring of 1979, the National Severe Storms Laboratory (NSSL) operated its $10 \mathrm{~cm}$ Doppler radar at Norman, Okla., in conjunction with Project SESAME '79 (Alberty et al., 1979). Nearby (within $200 \mathrm{~m}$ ) the Air Force Geophysics Laboratory (AFGL) $5 \mathrm{~cm}$ Doppler radar was collecting data for the Joint Doppler Operational Project (JDOP) (JDOP Staff, 1979; Glover, 1980). The technical specifications of the two radars are given in Table 1. The simultaneous operation of these two radars provides an excellent basis for comparison of 5 and $10 \mathrm{~cm}$ reflectivities ${ }^{4}$. Photos from the NSSL WSR-57 surveillance radar $(10 \mathrm{~cm})$ are also available.

\section{10 April 1979 storms}

During the afternoon of 10 April 1979, several large thunderstorms formed in northwest Texas and southwest Oklahoma, spawning numerous tornadoes. Between 1710 and 1820 (all

TABLE 1. Technical specifications for two Doppler radars.

\begin{tabular}{lll}
\hline \hline & NSSL Doppler & AFGL Doppler \\
\hline Beam width & $0.81^{\circ}$ & Az: $0.84^{\circ}$ \\
& (Circular) & El: $1.04^{\circ}$ \\
Transmitted power & $750 \mathrm{~kW}$ & $400 \mathrm{~kW}$ \\
Antenna gain & $46.8 \mathrm{~dB}$ & $45.0 \mathrm{~dB}$ \\
Wavelength & $10.52 \mathrm{~cm}$ & $5.45 \mathrm{~cm}$ \\
Pulse repetition frequency & $1302 \mathrm{~Hz}$ & $1302 \mathrm{~Hz}$ \\
\hline
\end{tabular}

\footnotetext{
${ }^{4}$ All NSSL and AFGL data discussed here were obtained from an antenna elevation angle of $0.5^{\circ}$.
} 


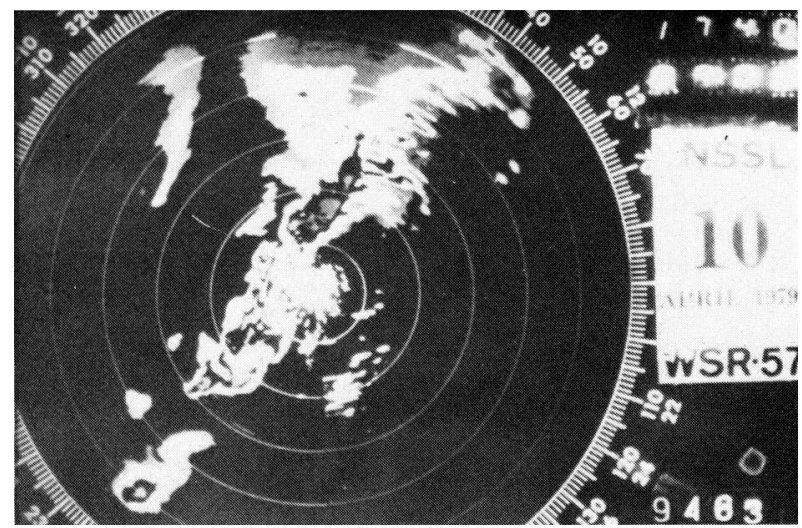

FIG. 1. NSSL WSR $-57\left(10 \mathrm{~cm}, 2^{\circ}\right.$ beam width, $0^{\circ}$ elevation $)$ at $1740 \mathrm{CST}$. First-level reflectivity is $19 \mathrm{~dB}(Z)$; second level is 25 $\mathrm{dB}(Z)$, with successive levels incremented in $10 \mathrm{~dB}(Z)$ steps. Range marks are $40 \mathrm{~km}$. Central core $\left(220^{\circ} / 70 \mathrm{~km}\right)$ is $55-65 \mathrm{~dB}(Z)$.
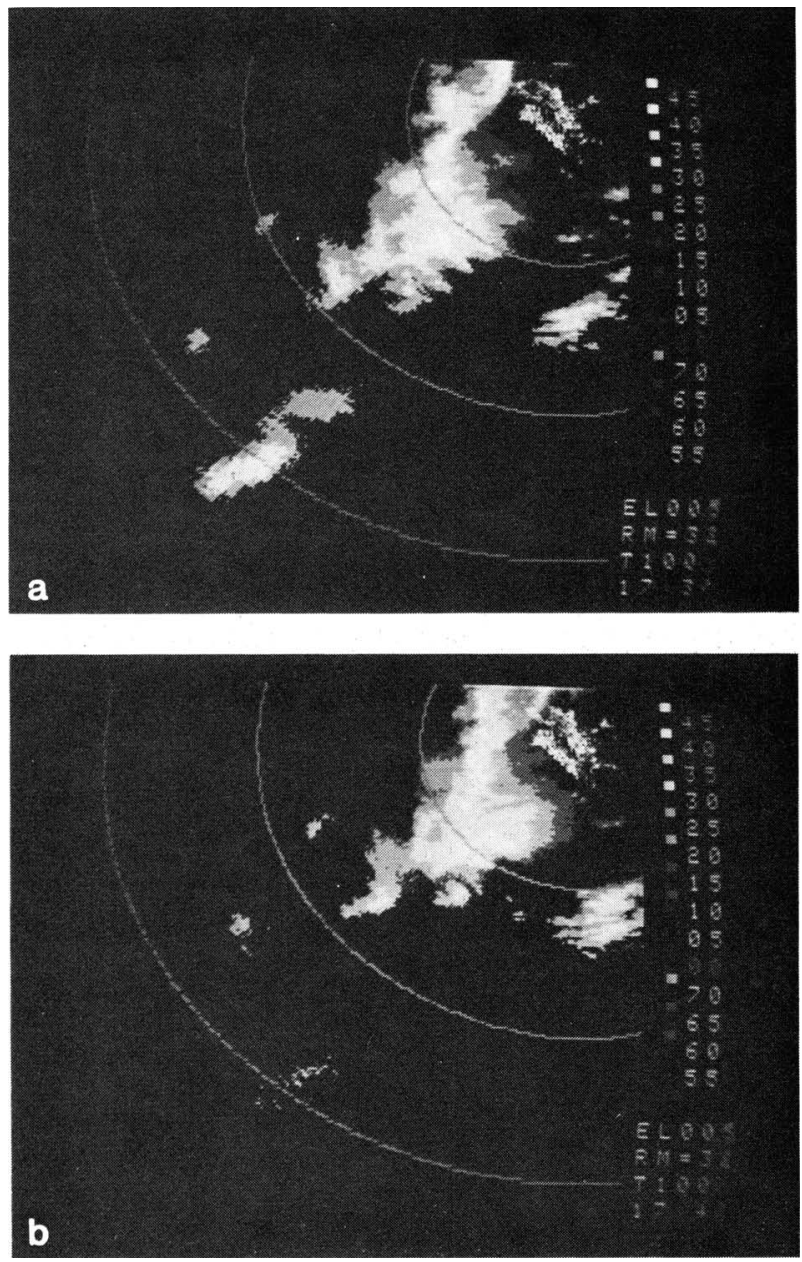

FIG. 2. AFGL Doppler $(5 \mathrm{~cm})$ reflectivities $\left(0.5^{\circ}\right.$ elevation): a) $1730 \mathrm{CST}$; b) $1742 \mathrm{CST}$. Range marks are $64 \mathrm{~km}$. These are reprints from a color display. Peak reflectivities are between 43 and 48 $\mathrm{dB}(Z)$ on both displays. The Wichita Falls storm is crossing the outer range circle. times are CST), the two Doppler radars collected simultaneous data on the storm systems southwest of Norman.

Figure 1 is taken from the NSSL WSR-57 radar at 1740. The far southwestern cell $\left(220^{\circ} / 194 \mathrm{~km}\right)$ spawned the tornadoes that passed near Seymour, Tex., at 1700 and Wichita Falls around 1800 , and will be referred to as the Wichita Falls storm. The near-range cell $\left(220^{\circ} / 70 \mathrm{~km}\right)$ spawned a tornado that began near Harrold, Tex., at 1555 and dissipated near Marlow, Okla., at 1740. This cell will be referred to as the Harrold-Marlow storm. Both storms were observed to have supercell characteristics on radar.

The speeds and directions of these two storms were slightly different. When viewed from Norman, the two storm centers moved into alignment around 1740 and out of alignment around 1830. This alignment resulted in attenuation of the Wichita Falls storm by the intervening Harrold-Marlow storm.

Figure $2 \mathrm{a}$ is taken from the AFGL $5 \mathrm{~cm}$ radar display at 1730. Attenuation of the western edge of the Wichita Falls storm is already in progress. Figure $2 \mathrm{~b}$, taken at 1742 , shows the severe attenuation of the $5 \mathrm{~cm}$ signal from the Wichita Falls storm (compare with the $10 \mathrm{~cm}$ signal at 1740, Fig. 1). Reports from several $10 \mathrm{~cm}$ radars show that the maximum reflectivity of the Wichita Falls storm was near $50 \mathrm{db}(Z)$ during the period $1730-1830$.

Some characteristics of the attenuation-producing Harrold-Marlow storm are known. Between 1740 and 1800, the storm was producing a swath of significant wind damage (not tornadic). Both 5 and $10 \mathrm{~cm}$ radars recorded the maximum reflectivity aloft to be continuously in excess of 55 $\mathrm{dB}(Z)$ between 1729 and 1803 . This suggests the presence of hail (Ward et al., 1965; Waldvogel and Federer, 1976). The locations and times of hail reports from the NSSL Volunteer Observer Network (Nelson and Young, 1979) are shown in Fig. 3. Telephone and newspaper surveys indicate reports (without exact time or location) of up to golfball-size hail.

At the time of Fig. 3, the storm was skirting the southeastern edge of the Agricultural Research Service (ARS) rain gage network. Gage separation is about $5 \mathrm{~km}$. The $10 \mathrm{~cm}$ reflectivity field and rainfall rates from the ARS network are superimposed on Fig. 3 to allow for comparison. Dashed rainfall rate isopleths indicate analysis in data-void regions and are based on the reflectivity pattern and assumed symmetry. Heaviest rainfall rates and highest reflectivities at $0.5^{\circ}$ elevation are between the $210^{\circ}$ and $220^{\circ}$ radials.

Figure $4^{5}$ shows the minimum loss in the far-range storm, since the small area of reflectivity return is at the minimum detectable signal (MDS) level (corresponding to about 28 $\mathrm{dB}(Z)$ at $190 \mathrm{~km}$ ) for the $5 \mathrm{~cm}$ radar. The maximum calculated attenuation is $23 \mathrm{~dB}$ at a range of $200 \mathrm{~km}$. Larger attenuation in the far-range storm would have been measured if MDS had been lower.

While the loss of the Wichita Falls storm $5 \mathrm{~cm}$ reflectivity after 1740 is quite apparent, significant attenuation also occurred on the back side of the near-range storm (Harrold-

${ }^{5}$ Figures 4-7 are constant-altitude objective analyses constructed from $0.5^{\circ}$ elevation data. Grid points on the horizontal plane were computed from data falling within a sphere centered on the grid points. 


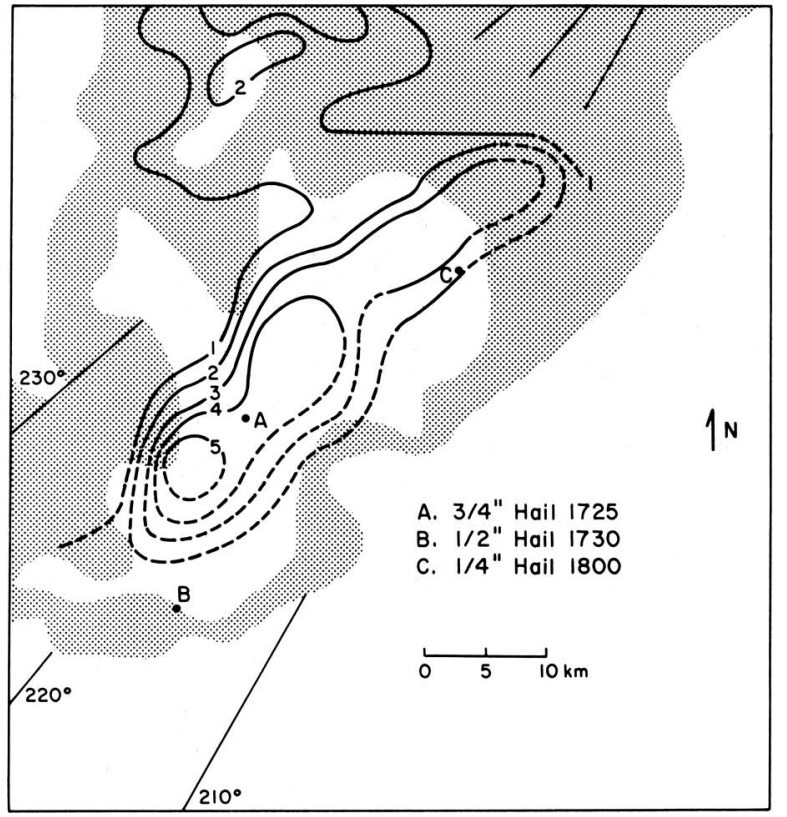

FIG. 3. Superimposed reflectivity $\left(1752 \mathrm{CST}, 0.5^{\circ}\right.$ elevation $)$ and rainfall rates. $10 \mathrm{~cm}$ shaded reflectivity is $20-40 \mathrm{db}(Z)$, nonshaded interior is greater than $40 \mathrm{~dB}(Z)$, isopleths are $15 \mathrm{~min}$ rainfall rates $\left(\right.$ in $\mathrm{h}^{-1}$ ) centered at 1752:30 CST. Dashed isopleths are extrapolated. Hail reports are from points A, B, and C. Selected azimuths from NSSL indicated.

Marlow). Figures 5, 6, and 7 show the total effect of attenuation on the near-range $5 \mathrm{~cm}$ reflectivity pattern at 1742 . Notice the peak $10 \mathrm{~cm}$ reflectivity greater than $55 \mathrm{~dB}(Z)$ and the appearance of the classical hook in Fig. 5. In Fig. 6, notice the degradation of the $5 \mathrm{~cm}$ reflectivity maxima, the distortion of the pattern and loss of the well-defined hook, and the complete loss of definition on the back side of the storm when compared with Fig. 5. Figure 7 shows the total signal loss due to attenuation in the near-range storm at 1742 . The

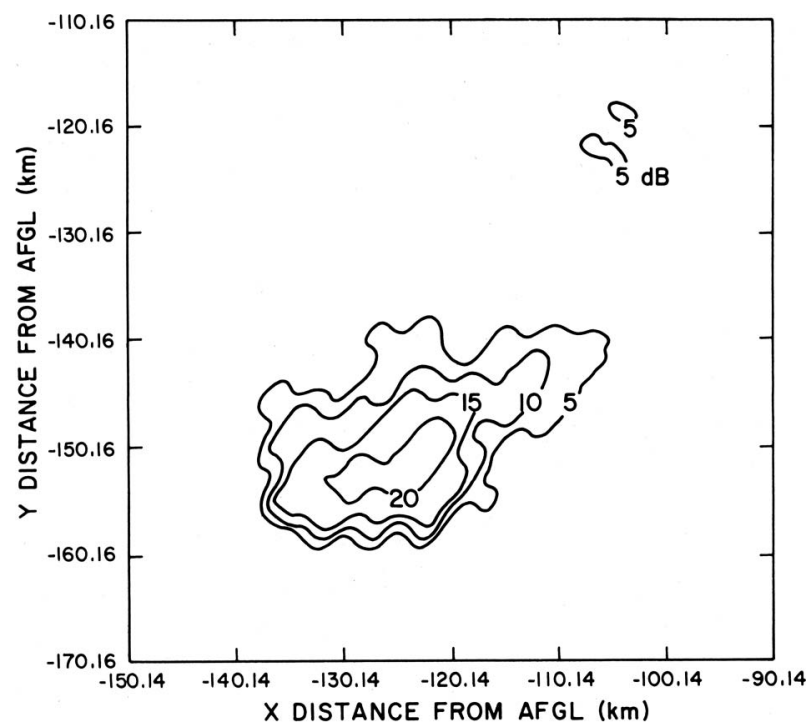

Fig. 4. Minimum $5 \mathrm{~cm}$ signal loss (dB) (far-range storm) due to attenuation $(10 \mathrm{~cm}$ reflectivity $-5 \mathrm{~cm}$ minimum detectable signal) at $1742 \mathrm{CST}$. Constant altitude (MSL) analysis, $4.2 \mathrm{~km}$.

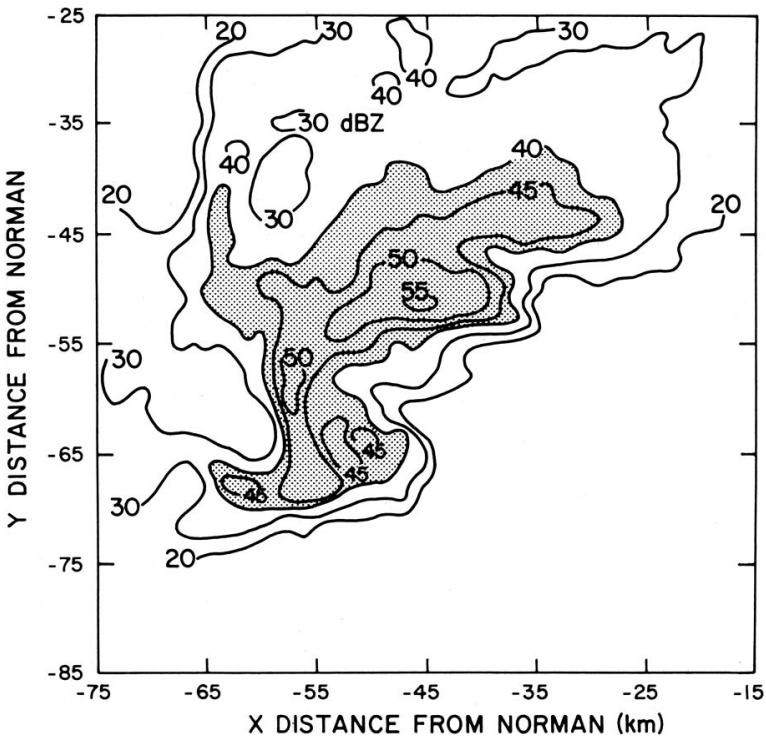

FIG. 5 . $10 \mathrm{~cm}$ reflectivity (near-range storm) at 1742 . Distance in kilometers. Constant altitude (MSL) analysis, $0.8 \mathrm{~km}$.

maximum attenuation is $25-30 \mathrm{~dB}$ at a range of $80 \mathrm{~km}$. The back side of the pattern is not closed, since differences were not computed if there was no $5 \mathrm{~cm}$ signal return (i.e., below MDS). Severe $5 \mathrm{~cm}$ attenuation of both storms continued with similar results until after 1800 . At 1753 , the near-range storm attenuation maximum was $30 \mathrm{~dB}$. No signal return (above MDS) occurred for the far-range storm for a period of about $18 \mathrm{~min}$, and no significant return appeared for about $45 \mathrm{~min}$.

While the Wichita Falls tornado devastated parts of Wichita Falls, the JDOP team had no $5 \mathrm{~cm}$ data on this storm and was forced to rely entirely on information from the $10 \mathrm{~cm}$ radar in appraising the storm's location, severity, movement, and velocity structure. In addition, the $5 \mathrm{~cm}$ velocity struc-

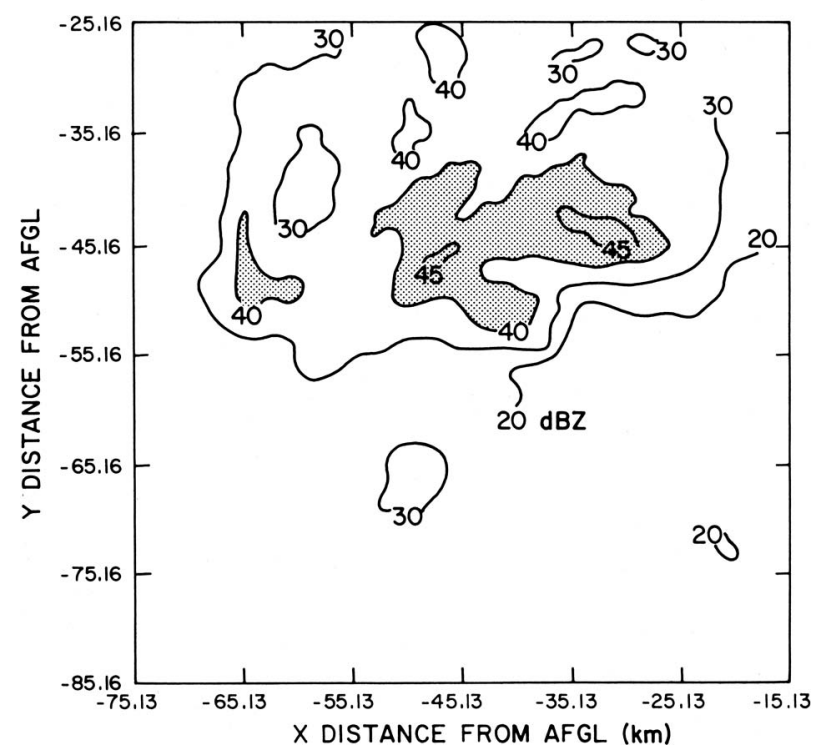

FIG. $6.5 \mathrm{~cm}$ reflectivity (near-range storm) at 1742 . Distance in kilometers. Constant altitude (MSL) analysis, $0.8 \mathrm{~km}$. 


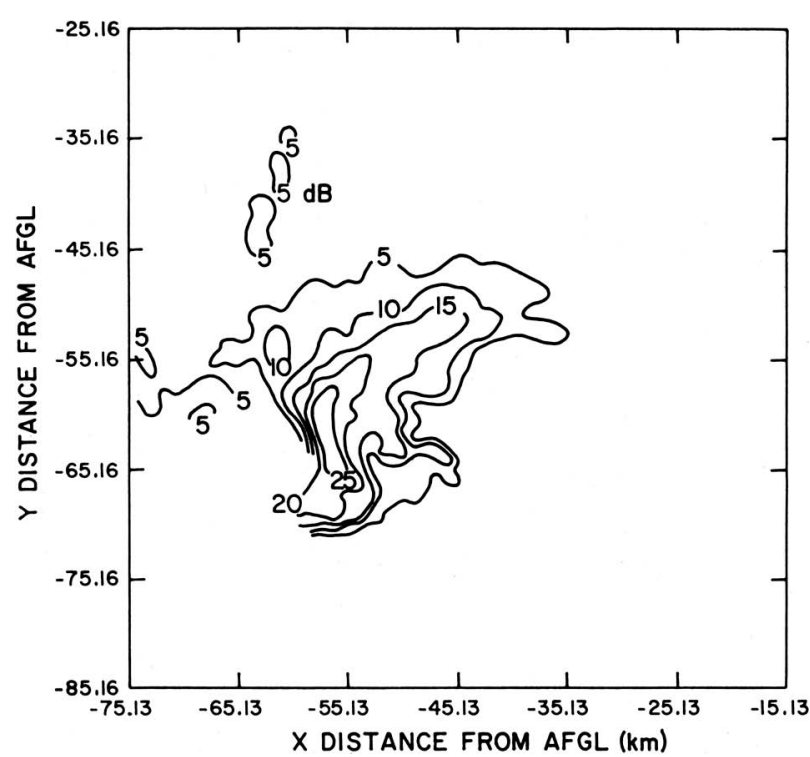

FIG. $7.5 \mathrm{~cm}$ signal loss in $\mathrm{dB}$ (near-range storm) due to attenuation at 1742. Distance in kilometers. Constant altitude analysis, 0.8 $\mathrm{km}$. Geographic grid center is identical for Figs. 5, 6, and 7.

ture of the near-range storm provided no information for pinpointing the location of severe weather.

\section{Summary and conclusions}

The Har rold-Marlow storm was severe, produced hail of $3 / 4$ in or larger, and had radar reflectivities in excess of $55 \mathrm{~dB}(Z)$ during the period 1730-1800. The maximum rainfall rate observed in the ARS network (1730-1800) associated with the Harrold-Marlow storm was $6.4 \mathrm{in} \mathrm{h}^{-1}$. The $5 \mathrm{~cm}$ radar signal along the $220^{\circ}$ radial experienced reflectivities well in excess of $40 \mathrm{~dB}(Z)$ and rainfall rates in excess of $2 \mathrm{in} \mathrm{h}^{-1}$ along a path length of $40 \mathrm{~km}$, and a significant but unknown path through hail. As a result, the $5 \mathrm{~cm}$ radar was unable to track a 50 $\mathrm{dB}(Z)$ tornadic storm $200 \mathrm{~km}$ away for about $45 \mathrm{~min}$ because of severe intervening precipitation. During this same time, the $10 \mathrm{~cm}$ radar continued to track both storms. The degradation of the $5 \mathrm{~cm}$ Harrold-Marlow storm reflectivity by its own attenuation also was significant, distorting and degrading the maximum values and related severe signatures. While the "perfect" alignment and strength of these storms may seem like a rare occurrence, it is not that unusual considering the normal arrangement of cells in a squall line. These cells, while strong, were not atypical of spring activity. In addition, the reported hail sizes were not exceptionally large. Thus, the problem of $5 \mathrm{~cm}$ attenuation may be more widespread than previously documented due to the relatively few cases of colocated radars.

The loss of reflectivity returns is not, of course, peculiar to Doppler radars. Identical reflectivity losses would be expected from a conventional (non-Doppler) radar with similar operating characteristics. In addition, loss of reflectivity signals from a Doppler also implies loss of velocity data from the same area. We did not examine the alteration of the remaining velocity field, although one would expect distortions in the velocity spectrum.

The National Weather Service operates a few $5 \mathrm{~cm}$ radars for local warning use, and the Air Weather Service radar network is composed almost entirely of $5 \mathrm{~cm}$ radars. The $\mathrm{Na}$ tional Weather Service network radars $(10 \mathrm{~cm})$ and all of the Air Weather Service radars will be replaced in the late 1980s by the Next Generation Weather Radar, a proposed $10 \mathrm{~cm}$ Doppler radar. On the other hand, most TV stations and private firms favor $5 \mathrm{~cm}$ radars, probably because of the much larger cost of the antennas required for $10 \mathrm{~cm}$ radars of comparable resolution. Meteorologists who use $5 \mathrm{~cm}$ radars for severe storm forecasting would be well advised to factor in the consideration of degraded radar performance during episodes of heavy rainfall.

Acknowledgments. Captain Allen's work on this study was funded at the University of Oklahoma by the Air Force Institute of Technology. The authors would like to thank Dr. Arlin Nicks and Mr. Frank Igo of the Agricultural Research Service, Southern Region, for their help in obtaining rainfall data. In addition, thanks go to the following people at NSSL: Chuck Clark and Joan Kimpel, for graphic support; Steve Nelson, for information on the Volunteer Observer Network; and Richard Clark, for computer support. Thanks go to Pio Petrocchi at AFGL for photographic support. The authors would also like to thank the many people at AFGL and NSSL participating in JDOP and SESAME '79, who helped in the collection of 5 and $10 \mathrm{~cm}$ data.

\section{References}

Alberty, R. L., D. W. Burgess, C. E. Hane, and J. F. Weaver, 1979: SESAME' 79 operations summary. ERL Ret. (SESAME Documentation Series), Boulder, Colo., 253 pp.

Allen, R. H., D. W. Burgess, and R. J. Donaldson, Jr., 1980: Severe 5 $\mathrm{cm}$ radar attenuation of the Wichita Falls storm by intervening precipitation. Preprints, 19th Conference on Radar Meteorology (Miami Beach), AMS, Boston, pp. 87-89.

Glover, K. M., 1980: On the automation of weather radar information for air and ground operations. Preprints, 19th Conference on Radar Meteorology (Miami Beach), AMS, Boston, pp. 118-124.

JDOP Staff, 1979: Final report on the Joint Doppler Operational Project (JDOP) 1976-78. NOAA Tech. Memo. NSSL-86, Norman, Okla., 84 pp.

Metcalf, J. I., 1980: Airborne weather radar and severe weather penetration. Preprints, 19th Conference on Radar Meteorology (Miami Beach), AMS, Boston, pp. 125-129.

Nelson, S. P., and S. K. Young, 1979: Characteristics of Oklahoma hailfalls and hailstorms. J. Appl. Meteorol., 18, 339-347.

Waldvogel, A., and B. Federer, 1976: Raindrops and the boundary between rain and hail. Preprints, 17th Conference on Radar Meteorology (Seattle), AMS, Boston, pp. 167-172.

Ward, N. B., K. E. Wilk, and W. C. Herrmann, 1965: WSR-57 reflectivity measurements and hail observations. ESSA Tech. Note 3 , NOAA Tech. Memo. NSSL-24, Norman, Okla., pp. 1-8.

Wilson, J. W., 1978: Comparison of C- and S-band radar reflectivities in northeast Colorado hailstorms. Preprints, 18th Conference on Radar Meteorology (Atlanta), AMS, Boston, pp. 271-275. • 